\title{
PEMAKNAAN PERANG TANDA PAGAR '\#’ ANTAR DUA KUBU CALON PRESIDEN INDONESIA 2019 DI MEDIA SOSIAL (Analisis Semiotika Peirce Pada Sampul Majalah Tempo Edisi 04 Juni 2018)
}

\author{
Linna Friska Marbun ${ }^{1)}$, Lasmery RM Girsang ${ }^{2 * *}$ \\ 1) Ilmu Komunikasi, Universitas Bunda Mulia \\ 2) Ilmu Komunikasi, Universitas Bunda Mulia
}

\begin{abstract}
ABSTRAK
Menjelang kegiatan Pemilihan Umum (Pemilu) pada bulan April 2019, perseteruan tanda pagar (tagar)/\#/hashtag \#2019GantiPresiden dan \#Jokowi2Periode semakin hari semakin marak di media sosial. Perang tagar tersebut merepresentasikan perbedaan dukungan antara kubu pro Pemerintah Joko Widodo dan kubu yang tidak ingin Joko Widodo terpilih kembali menjadi Presiden pada periode 2019-2024.

Majalah TEMPO sebagai majalah yang menyajikan berita mengenai Politik, menerbitkan perseteruan yang terjadi di media sosial tersebut pada edisi 04 Juni 2018 dengan tema "PERANG\#ADU KUAT DI MEDIA SOSIAL MENJADI PEMANASAN MENJELANG PEMILU 2019. SIAPA BERADA DI BELAKANG DUA KELOMPOK BERSETERU?".

Melalui hasil Analisis Semiotika Peirce yang mengemukakan teori segitiga makna, yaitu: sign, object, dan interpretant, peneliti berhasil memperoleh makna bahwa sampul majalah TEMPO edisi 04 Juni 2018 menggambarkan keadaan Pemerintah pada masa akhir jabatan Joko Widodo sebagai Presiden Indonesia ke-7 yang tengah merasakan ketidaknyamanan dan kecemasan, akibat maraknya serangan tanda pagar atau hashtag dari kubu lawan di media sosial.

Tujuan dan manfaat dari penelitian ini selain untuk menguak makna grafis dan teks yang terdapat pada sampul Majalah TEMPO edisi 04 Juni 2018 dengan mengunakan model analisis Semiotika Peirce, juga untuk memberikan sumbangan pemikiran kepada khalayak luas, khususnya pembaca untuk menyikapi bahwa sebuah gambar ilustrasi pada sampul majalah tidak hanya sebagai cara untuk menarik minat khalayak dalam membeli majalah. Lebih dari itu, gambar ilustrasi sebenarnya memiliki makna mendalam berkaitan dengan isi berita yang dimuat suatu majalah.

Kata Kunci: Semiotika, Charles Sander Peirce, Majalah TEMPO, Tagar
\end{abstract}

\section{ABSTRACT}

Ahead of the General Election (Election) in April 2019, the hashtag / \# / hashtag \# 2019GantiPresiden and \# Jokowi2Periode period are increasingly rife on social media. The hashtag war represented a difference in support between the pro-Joko Widodo government and those who did not want Joko Widodo to be re-elected as President in the 2019-2024 period.

TEMPO magazine, as a magazine that presents news about politics, published a dispute that occurred on social media in the June 4, 2018 edition with the theme "WAR \# STRONG ADUES IN SOCIAL MEDIA BECOME WARMING AGAINST ELECTION 2019. WHO WAS BEING BEHIND THE TWO GROUPS UNDERSTANDING?".

Through the results of Peirce's Semiotic Analysis which proposes the theory of triangles of meaning, namely: sign, object, and interpretant, the researcher succeeded in obtaining the meaning that the cover of the June 4th edition of TEMPO magazine illustrates the state of the Government at the end of Joko Widodo's

\footnotetext{
${ }^{*}$ Korespondensi Penulis

Email: linnafriskaaa@gmail.com

lgirsang@bundamulia.ac.id
} 
term as the 7th President of Indonesia who was feeling discomfort and anxiety, due to the rise of fence attacks or hashtags from the opposing camp on social media.

The purpose and benefits of this research are not only to uncover the graphic and text meanings contained on the cover of the June 042018 edition of TEMPO Magazine by using the Peirce Semiotic analysis model, also to contribute ideas to a wide audience, especially readers to respond to an illustrated picture on the cover of the magazine not only as a way to attract public interest in buying magazines. More than that, the illustrated image actually has a deep meaning related to the news content published in a magazine.

Keywords: Semiotics, Charles Sander Peirce, TEMPO Magazine, Tagar

\section{PENDAHULUAN}

Perseteruan \#/tagar (tanda pagar) atau hashtag, semakin hari semakin marak di media sosial menjelang kegiatan Pemilihan Umum (Pemilu) pada bulan April 2019 untuk memilih Presiden dan Wakil Presiden yang nantinya akan memimpin NKRI untuk periode tahun 2019-2024. Pada 2017, tercatat ada 125 juta hashtag yang digunakan setiap harinya. Di 2018, salah satu hashtag yang ramai dalam konteks sikap sebuah kelompok adalah \#DiaSibukKerja dan \#2019gantipresiden yang merepresentasikan perbedaan dukungan di kedua belah pihak kandidat.

Di dunia nyata, gesekan antara dua kelompok yang berbeda bisa terjadi karena gagasan dari sebuah hashtag yang berubah menjadi simbol dari sikap. Sebelumnya, sekelompok orang berkaos \#2019GantiPresiden melakukan tindakan intimidasi terhadap beberapa orang di kawasan Car Free Day (CFD), Bundaran Hotel Indonesia (Jakarta Pusat) pada Minggu 29 April 2018 pukul 09:15 WIB. Kejadian yang banyak menjadi sorotan ini menggambarkan hashtag telah jadi simbol jargon-jargon politik pada kaos.

Di ranah maya, melalui Tweet Reach, layanan analisis Twitter, terjadi pertarungan yang berimbang antara dua hashtag tersebut. Pada 30 April 2018 antara pukul 07:30- 08:00 WIB, hashtag \#DiaSibukKerja telah menyebar pada 93.644 akun twitter, hashtag tersebut sudah dilihat 122.771 kali. Sementara itu, \#2019gantipresiden, diukur dengan kerangka waktu yang sama telah menjangkau 96.054 akun twitter. \#2019gantipresiden tercatat sudah dilihat
114.917 kali. Kedua hashtag tersebut hampir memiliki nilai keterjangkauan yang sama. Namun, dilihat melalui Tweet Reach keduanya memiliki pondasi yang berbeda. Hashtag \#DiaSibukKerja mayoritas dengan persentase sebanyak $49 \%$ dikicaukan oleh akun-akun Twitter yang memiliki jumlah pengikut kurang dari 1.000. Sementara itu, hashtag \#2019gantipresiden secara umum lebih banyak, dengan persentase sebesar $42 \%$ dikicaukan oleh akun-akun yang memiliki pengikut kurang dari 100 (https://tirto.id/evolusi-tagar-dari-simboldigital-jadi-perang-slogan-dunia-nyatacJFy).

Jokowi sendiri tampaknya menganggap tagar sebagai urusan penting dan oleh karenanya layak ditanggapi. Di depan pendukungnya di Bogor (Jawa Barat), beliau menyebutkan hanya bisa diganti oleh rakyat, bukan oleh kaus bertuliskan \#2019GantiPresiden.

Bukan meredakan, komentar itu malah melambungkan popularitas tanda pagar tersebut hingga tiga kali lipat. 'Lalu lintas' di dunia maya menunjukkan popularitas tagar penentang Jokowi unggul dibanding pendukung Presiden (dikutip dari majalah TEMPO edisi 04 Juni 2018, hal.25).

Oleh karenanya, berdasarkan pengumuman resmi Komisi Pemilihan Umum (KPU) tentang daftar calon presiden dan wakil presiden, terpaparkan secara jelas bahwa fokus perilaku masyarakat dari adanya perang \# di media sosial ditujukan untuk mendukung dan juga menjatuhkan salah satu dari calon presiden dan wakil presiden yang terbagi dalam dua kubu. Adapun kubu nomor urut 01 (Joko WidodoMa'ruf Amin) sedangkan kubu nomor urut 02 (Prabowo Subianto-Sandiaga Uno) yang 
dipilih oleh rakyat dalam Pemilu pada 17 April 2019.

Jika perang \# ini adalah sebuah bentuk kampanye, maka kampanye ini merupakan sebuah kampanye terbaru dan berbeda dari kampanye untuk pemilihan Presiden yang telah terjadi beberapa tahun belakangan ini. Kampanye pada prinsipnya merupakan suatu proses kegiatan komunikasi individu atau kelompok yang dilakukan secara terlembaga dan bertujuan untuk menciptakan suatu efek atau dampak tertentu.

Berdasarkan literatur dari Venus (2009) tersebut, perang \# dapat termasuk dalam ciri-ciri kampanye, jika dikaji satu persatu, perang \# merupakan tindakan komunikasi yang terencana dengan tujuan untuk menciptakan efek tertentu pada sejumlah besar khalayak. Sementara Rogers dan Storey (1987) mendefinisikan kampanye sebagai serangkaian tindakan komunikasi yang terencana dengan tujuan untuk menciptakan efek tertentu pada sejumlah besar khalayak yang dilakukan secara berkelanjutan pada kurun waktu tertentu (dalam Venus, 2009:7).

Sangat jelas bahwa 'perang' \# melibatkan banyak masyarakat di Indonesia yang berpartisipasi dalam membuat postingan dan cuitan mengenai \# yang ditujukan untuk kubu tertentu, seperti \#2019GantiPresiden atau pun \#2019TetapJokowi.

Penggunaan \# di media sosial sebagai kampanye untuk menggiring opini dan memenangkan simpati rakyat dalam memberikan dukungan terhadap salah satu pasangan calon presiden dan wakil presiden yang akan menjabat pada periode 20192024 merupakan hal baru dari kampanye pemilihan calon presiden dan wakil presiden tahun-tahun sebelumnya yang lebih banyak menggunakan media massa (televisi).

Peralihan dan pemilihan media baru (media sosial) turut dikritisi melalui tampilan cover dari sebuah majalah yang bereputasi di Indonesia. Adalah majalah TEMPO yang terbit setiap minggu. Berisi liputan berita mengenai investigasi, hukum, politik, ekonomi dan bisnis yang terjadi di dalam (nasional) dan luar negeri (internasional) dengan tampilan sampul yang unik dan beragam pada setiap edisinya.

TEMPO edisi 04 Juni 2018 hal. 32 memaparkan bagaimana para penentang Presiden Joko Widodo konsisten melekatkan \#2019GantiPresiden dalam unggahan di media sosial. Sedangkan keberhasilan pemerintah lebih banyak digaungkan akun media sosial Jokowi seorang diri. Seperti yang terlihat pada gambar berikut:
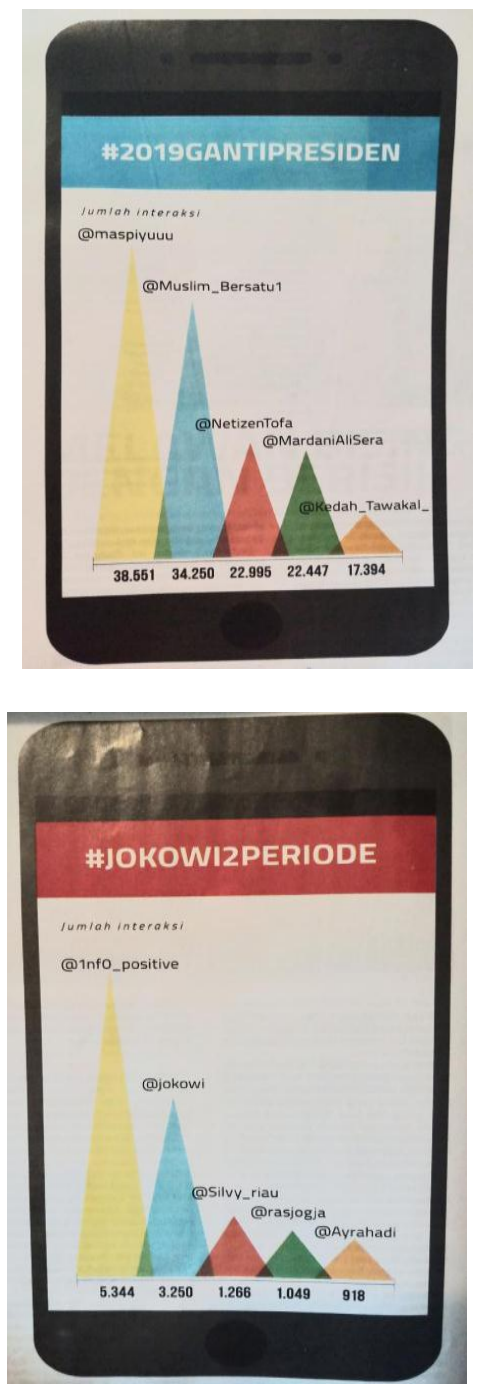

Gambar 1: Perang Tagar di Media Sosial

\section{Rumusan Masalah}


Berdasarkan latar belakang yang telah diuraikan maka peneliti ingin menganalisis, menguak dan mengetahui "Apakah makna dari grafis dan teks yang terdapat pada sampul majalah TEMPO edisi 04 Juni 2018 mengenai isu pemberitaan "PERANG \# ADU KUAT DI MEDIA SOSIAL MENJADI PEMANASAN MENJELANG PEMILU 2019. SIAPA BERADA DI BELAKANG DUA KELOMPOK YANG BERSETERU?"

\section{TINJAUAN PUSTAKA}

\section{Semiotika}

Penelitian yang masuk kedalam tradisi semiotika ini-menurut Littlejohn (2014: 53-54)—menjadi tradisi pemikiran yang penting dalam teori komunikasi. Tradisi semiotik terdiri atas sekumpulan teori tentang bagaimana tanda-tanda merepresentasikan benda, ide, keadaan, situasi, perasaan, dan kondisi diluar tandatanda itu sendiri. Penyelidikan tanda-tanda tidak hanya memberikan cara untuk melihat komunikasi, melainkan memiliki pengaruh yang kuat pada hampir semua perspektif yang sekarang diterapkan pada teori komunikasi.

Konsep dasar yang menyatukan tradisi ini adalah tanda (sign) yang didefinisikan sebagai stimulus yang menandakan atau menunjukkan beberapa kondisi lain. Konsep dasar kedua adalah symbol (symbol) yang biasanya menandakan tanda yang kompleks dengan banyak arti, termasuk arti yang sangat khusus. Beberapa ahli memberikan perbedaan yang kuat antara tanda dan simbol-tanda dalam realitasnya memiliki referensi yang jelas terhadap sesuatu, sedangkan simbol tidak.

Dengan perhatian pada tanda dan simbol, semiotik menyatukan kumpulan teori-teori yang sangat luas yang berkaitan dengan bahasa, wacana, dan tindakantindakan noverbal. Kebanyakan pemikiran semiotik melibatkan ide dasar triad of meaning yang menegaskan bahwa arti muncul dari hubungan di antara tiga hal: benda (atau yang dituju), manusia (penafsir), dan tanda.

Semiotik selalu dibagi ke dalam tiga wilayah kajian-semantik, sintaktik, dan pragmatik. Semantik berbicara tentang bagaimana tanda-tanda berhubungan dengan yang ditunjuknya oleh tanda-tanda. Semiotik menggambarkan dua dunia-dunia benda dan dunia tanda-dan mencerahkan hubungan di antara kedua dunia tersebut. Kapan pun kita memberikan sebuah pertanyaan "Apa yang direpresentasikan oleh tanda?" maka kita berada dalam ranah semantik.

Wilayah kajian kedua dalam semiotik adalah sintaktik atau kajian hubungan di antara tanda-tanda. Tanda-tanda sebetulnya tidak pernah berdiri dengan sendirinya. Hampir semuanya selalu menjadi bagian dari sistem tanda atau kelompok tanda yang lebih besar yang diatur dalam cara-cara tertentu. Oleh karena itu, sintaktik mengacu pada aturan-aturan yang dengannya orang mengombinasikan tanda-tanda ke dalam sistem makna yang kompleks. Semiotik tetap mengacu pada prinsip bahwa tanda-tanda selalu dipahami dalam kaitannya dengan tanda-tanda lain

Sedangkan pragmatik, kajian utama semiotik yang ketiga, memperlihatkan bagaimana tanda-tanda membuat perbedaan dalam kehidupan manusia atau penggunaan praktis serta berbagai akibat dan pengaruh tanda pada kehidupan sosial. Cabang ini memiliki pengaruh yang paling penting dalam teori komunikasi karena tanda-tanda dan sistem tanda dilihat sebagai alat komunikasi manusia.

Sebagai peletak dasar semiotika, Charles Sanders Peirce (1893-1941) membagi tanda dan cara kerjanya ke dalam tiga kategori sebagaimana tampak dalam tabel diatas. Meski begitu dalam praktiknya, tidak menjadi simbol. Banyak simbol yang berupa ikon. Disamping menjadi indeks, sebuah tanda sekaligus juga berfungsi sebagai simbol.

Peneliti akan menggunakan semiotika Peirce ini sebagai metode analisis untuk mengkaji dan mengetahui makna apa 
saja yang terdapat pada sampul majalah TEMPO edisi 04 Juni 2018 dengan membedakan tipe-tipe tanda menjadi: Ikon (icon), Indeks (index), dan Symbol (symbol) yang didasarkan atas relasi di antara representamen dan objeknya.

\section{Komunikasi Politik}

Menurut Dahlan, komunikasi politik ialah satu bidang atau disiplin yang menelaah perilaku dan kegiatan komunikasi yang bersifat politik mempunyai akibat politik, atau berpengaruh terhadap perilaku politik. Maka jika bertolak dari konsep komunikasi dan konsep politik, pengertian komunikasi politik dapat dirumuskan sebagai suatu proses pengoperan lambang-lambang atau simbol-simbol komunikasi yang berisi pesanpesan politik dari seseorang atau kelompok kepada orang lain, dengan tujuan untuk membuka wawasan atau cara berpikir, serta mempengaruhi sikap dan tingkah laku khalayak yang menjadi target politik (dalam Cangara, 2010:32-35).

Dalam penelitian 'perang \#' yang sedang marak di media sosial, komunikasi politik yang terjadi yaitu dengan adanya pengoperan lambang-lambang atau simbolsimbol komunikasi yang berisi pesan-pesan politik dari seseorang atau kelompok kepada orang lain yaitu berupa sebuah postingan atau cuitan pada media sosial facebook, twitter, instagram, dan sebagainya yang menyertakan tanda pagar '\#' atau yang biasa disebut hastag pada media sosial yang bertuliskan \#2019GantiPresiden maupun \#Jokowi2Periode.

Narasi yang terbangun oleh kajian komunikasi politik adalah peran perantara (mediator) antara pemerintah dan masyarakat (warga negara) sebagai penyampaian pesan yang bermuara pada pemenuhan kebutuhan. Untuk menjelaskan fungsi komunikasi politik dapat dilihat dengan beberapa indikasi sebagai berikut:

Pertama, komunikasi politik adalah suatu strategi untuk mendapatkan dukungan dan pemenuhan terhadap kebutuhan dalam sistem politik, dengan asumsi demikian dapat dicontohkan dengan pemenuhan kepentingan, mengambil keuntungan melalui kebijakan dan strategi politik.

Kedua, komunikasi politik sebagai alat penghubung antara rakyat dan pemerintah, baik dalam hal mobilisasi sosial untuk implementasi hubungan, memperoleh dukungan, kepatuhan dan juga integrasi politik. Komunikasi juga berfungsi sebagai rangsangan terhadap tanggapan aktif (feedback) atas sejumlah stimulus (output). Output tersebut berupa kebijakan pemerintah, masyarakat adalah bagian penting sebagai penerima atau penolak terhadap kebijakan.

Ketiga, komunikasi politik memiliki peran sebagai pemberi ancaman untuk memperoleh loyalitas (kepatuhan) sebelum alat paksa digunakan. Secara sederhana, komunikasi sebagai pintu perundingan awal dalam menentukan atau pengambilan kebijakan.

Keempat, komunikasi politik memberikan nilai etika terhadap pergerakan politik sehingga mampu menguasai homogenitas yang relatif tinggi. Nilai homogenitas politik memiliki pengaruh terhadap stabilitas politik.

Kelima, komunikasi politik juga mampu menjadi pengontrol sosial yang memliki idealisasi sosial dan keseimbangan politik.

Dari kelima uraian tersebut, dapat dipahami secara garis besar komunikasi politik adalah bagian penting sebagai jalan mencapai keteraturan, ketertiban, dan keharmonisan dalam wilayah kehidupan bernegara. Selain itu, ada dua hal penting yang menjadi komunikasi politik, kedua hal tersebut menjadi penyeimbang berjalannya perpolitikan pemerintah (Putra, 2012:47-48).

Di majalah TEMPO edisi 04 Juni 2018 halaman 31, komunikasi politik yang dilakukan oleh Pemerintah dalam menanggapi maraknya \#2019GantiPresiden dijabarkan dalam kutipan berikut "Diserang tanpa henti di media sosial melalui tanda pagar \#2019GantiPresiden, pihak istana berusaha menangkis". Sejumlah penjabat di istana yang ditemui TEMPO mengatakan pemerintah menyiapkan berbagai strategi 
untuk memerangi tagar tersebut. Narasi utamanya adalah menyampaikan pencapaian positif pemerintah.

Berdasarkan penjabaran Michael Rush dan Phillip Althoff (dikutip dari majalah TEMPO), tujuan komunikasi politik yang dilakukan pemerintah saat ini adalah proses pertukaran informasi di antara individu-individu dengan kelompokkelompoknya pada semua tingkatan masyarakat, untuk menyebarkan hasil dari pencapaian positif pemerintah selama Jokowi menjabat sebagai Presiden serta untuk menangkis isu-isu negatif pada tagar \#2019GantiPresiden yang disebarluaskan kepada masyarakat.

Komunikasi politik menjelang pemilihan presiden dalam Pemilu April 2019 mendatang gencar dilakukan oleh netizen dan juga elit politik dari kedua kubu dengan tagar andalan mereka masing-masing yaitu \#2019GantiPresiden serta \#Jokowi2Periode melalui media sosial seperti Twitter, Facebook, Instagram dengan tujuan untuk membuka wawasan atau cara berpikir, serta mempengaruhi sikap dan tingkah laku khalayak yang menjadi target politik, yaitu masyarakat yang mempunyai hak dan kewajiban memberikan suara mereka pada Pemilu bulan April 2019 medatang.

\section{Media}

Dalam penelitian ini, setidaknya ada dua jenis media yang difokuskan yakni media cetak (majalah) dan media sosial baru (instagram). Sebagai komunikator dalam komunikasi massa, majalah TEMPO menyebarkan pesan-pesannya kepada khalayak (pembacanya) dengan tujuan berbagi pengertian, penafsiran, informasi, hiburan, dan lain sebagainya.

Lain halnya dengan media sosial yang memberikan ruang kepada pengguna untuk menyuarakan pikiran dan opini mereka dalam proses demokratisasi. Selain tidak dibatasi oleh struktur dan tingkatan organisasi, melalui kekuatan khalayak di media sosial segala bentuk isu dapat menjadi perhatian publik dan akhirnya sampai kepada para pemimpin politik (Nasrullah, 2015:152).
Lebih khusus lagi, tujuan dibuatnya instagram (yang menjadi bagian dari media sosial baru) bukanlah hanya menawarkan aplikasi foto, melainkan sebuah cara baru berkomunikasi lewat gambar dan merupakan komunikasi yang berbeda. Karena pada dasarnya, aplikasi pengolah foto adalah sebuah alat (Atmoko, 2012, 10-13).

\section{Tanda Pagar (\#)}

Hashtag alias pound sign alias tanda pagar merupakan salah satu fitur yang dimiliki twitter, dirilis pada Agustus 2007. Pada awalnya digunakan untuk memudahkan para pengguna twitter mengikuti suatu perbincangan dengan tema tertentu.

Meskipun bertujuan sebagai sebuah penanda, hashtag telah melangkah lebih jauh, terutama dalam konteks sosial politik. Hashtag telah berevolusi lebih dari hanya sebatas simbol digital dunia maya. Hashtag sukses memengaruhi pemilihan umum hingga memicu gerakan sosial. Kesuksesan hashtag bertransformasi dari simbol digital menuju penggerak sosial.

Chris Messina, advokat spesialis di bidang open source, yang merupakan sosok pencetus ide hashtag, mengatakan pada The New York Times bahwasanya simbol hashtag merupakan "jalan paling kuat untuk berpartisipasi di media sosial." Sebagai simbol digital, hashtag merupakan sesuatu yang "kuat dan diperlukan" terutama untuk membangkitkan kesadaran bersama.

Dalam perkembangannya, hastag difungsikan untuk menggolongkan tema atau topik yang lebih spesifik dalam media sosial, dan di sisi lain hashtag juga mempermudah orang lain untuk mencari topik yang saling berhubungan. Dalam dunia digital, khususnya digital konten marketing pada media sosial, hashtag berguna untuk mengelompokkan sebuah tema atau informasi produk agar orang lain atau calon konsumen dapat menemukan informasi yang anda sampaikan pada sebuah artikel dengan hashtag tertentu.

Secara umum, hashtag sendiri memiliki beberapa fungsi yaitu (1) Mempermudah Pengelompokkan Konten; (2) 
Mempermudah Pencarian Konten; (3) Memperluas Posting-an; serta (4) Sebagai Sarana Promosi Produk (http://organixdigital.com/blog/read/definisi-dan-fungsihashtag-pada-sosial-media).

\section{METODOLOGI PENELITIAN}

Bersandar pada paradigma konstruktivis, penelitian berbasis pada pemikiran umum tentang teori-teori yang dihasilkan oleh peneliti dan teoritisi aliran konstruktivis. Littlejhon mengatakan bahwa teori aliran ini berlandaskan pada ide bahwa realitas bukanlah bentukan yang objektif, tetapi dikonstruksi melalui proses interaksi dalam kelompok, masyarakat, dan budaya.

Paradigma konstruktivis dapat dijelaskan melalui empat dimensi seperti diutarakan Hidayat, sebagai berikut:

1. Ontologis: relativism, realitas merupakan konstruksi sosial. Kebenaran suatu realitas bersifat relatif, berlaku sesuai konteks spesifik yang dinilai relevan oleh pelaku sosial

\section{Epistemologis:}

transactionalist/subjectivist, pemahaman tentang suatu realitas atau temuan suatu penelitian merupakan produk interaksi antara peneliti dengan yang diteliti.

3. Axiologis: Nilai, etika, dan pemilihan moral merupakan bagian yang tak terpisahkan dari suatu penelitian. Peneliti sebagai passionate participant, fasilitator yang menjembatani keragaman subjektivitas pelaku sosial. Tujuan penelitian lebih kepada rekonstruksi realitas sosial secara dialektis antara peneliti dengan pelaku sosial yang diteliti.

4. Metodologis: menekankan empati, dan interaksi dialektis antara peneliti dengan responden untuk merekonstruksi realitas yang diteliti melalui metode metode kualitatif seperti participant observation. Kriteria kualitas penelitian aunthenticity dan reflectivity: sejauh mana temuan merupakan refleksi otentik dari realitas yang dihayati oleh para pelaku sosial. (dalam Wibowo, 2011:28)

Sementara, pendekatan penelitian yang digunakan adalah kualitatif. Hal itu disebabkan karena asumsi dasar semiotika adalah kajian tentang tanda, dimana dalam memaknainya setiap orang akan berbedabeda. Sesuai dengan budaya, ideologi, pengalaman, dan sebagainya. Dengan demikian, analisis semiotika akan lebih sesuai menggunakan pendekatan kualitatif karena metode penelitian kualitatif bersifat subjektif sehingga instrumen penelitiannya adalah peneliti sendiri (Vera, 2014: 9-11).

Lebih jauh, Bogdan dan Taylor mendefinisikan metodologi penelitian kualitatif sebagai prosedur penelitian yang menghasilkan data deskriptif berupa katakata tertulis atau lisan dari orang-orang dan perilaku yang dapat diamati. Menurut Richie, penelitian kualitatif adalah upaya untuk menyajikan dunia sosial, dan perspektifnya di dalam dunia, dari segi konsep, perilaku, persepsi, dan persoalan tentang manusia yang diteliti. Kembali pada definisi di sini dikemukakan tentang peranan penting dari apa yang seharusnya diteliti yaitu konsep, perilau persepsi, dan persoalan tentang manusia yang diteliti (dalam Moleong, 2010:4,6).

Dari kajian tentang definisi-definisi tersebut, dapatlah disintesiskan bahwa penelitian kualitatif adalah penelitian yang bermaksud untuk memahami fenomena tentang apa yang dialami oleh subjek penelitian misalnya perilaku, persepsi, motivasi, tindakan secara holistik, dan dengan cara deskripsi dalam bentuk kata-kata dan bahasa, pada suatu konteks khusus yang alamiah dan dengan memanfaatkan berbagai metode alamiah (Moleong, 2010:6).

Yang terakhir, penelitian ini juga berjenis penelitian deskriptif. Penelitian deskriptif bermaksud memberikan gambaran suatu gejela sosial tertentu, sudah ada informasi mengenai gejala sosial seperti yang dimaksudkan dalam suatu permasalahan penelitian namun belum memadai. Penelitian deskriptif menjawab pertanyaan apa 
penjelasan yang lebih terperinci mengenai gejala sosial seperti yang dimaksudkan dalam suatu permasalahan penelitian yang bersangkutan. Penelitian deskriptif dilakukan terhadap variabel mandiri, yaitu tanpa membuat perbandingan atau menghubungkan dengan variabel yang lain (Wibowo, 2011:27).

\section{Unit Analisis}

Peneliti menetapkan tiga objek yang menjadi unit analisis yang terdapat pada sampul majalah TEMPO edisi "Perang \#" edisi 04 Juni 2018. Selanjutnya diklasifikasikan berdasarkan grafis dan teks yang dirangkum peneliti kedalam tabel berikut:

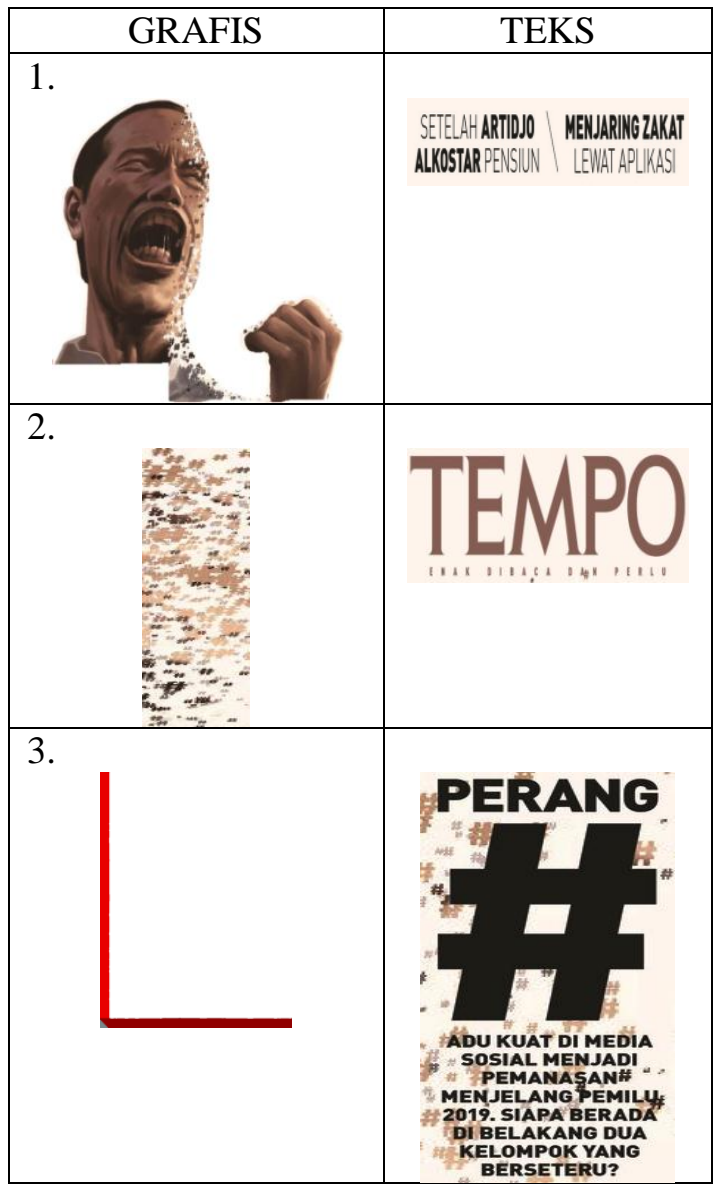

\section{Teknik Pengumpulan Data}

Peneliti menggunakan dua sumber data, yaitu data primer dan data sekunder.
Data primer yang peneliti gunakan berasal dari sampul majalah TEMPO edisi Juni 2018 yang membahas mengenai isu "Perang \#". Kemudian peneliti membagi sampul majalah TEMPO tersebut menjadi beberapa bagian untuk diteliti lebih mendalam. Alasan peneliti memilih sampul majalah TEMPO edisi Juni 2018, karena pada edisi ini mengangkat isu mengenai "Perang \#" yang tengah ramai di media sosial, khususnya bagi masyarakat di Indonesia. Fenomena tersebut menggambarkan bahwa saat ini, media sosial bukan lagi menjadi ajang saling berinteraksi untuk menambah relasi pertemanan. Melainkan perseteruan juga sangat mungkin terjadi di media sosial dewasa ini. Salah satu caranya yaitu melalui "Perang \#" seperti yang diilustrasikan pada sampul TEMPO edisi Juni 2018.

Sementara data sekunder mengandalkan studi literatur dari buku, jurnal ilmiah dan artikel internet. Hasil data secara sekunder dilakukan dengan melengkapi data yang diperoleh berupa intansi-intansi yang terkait dalam penelitian.

\section{Teknik Analisis Data}

Peneliti menggunakan analisis semiotika model Charles Sander Pierce. Dimana Peirce yang mengemukakan teori segitiga makna, yaitu:

(1) Representamen; bentuk yang diterima oleh tanda atau berfungsi sebagai tanda (Saussure menamakannya signifier). Representamen kadang diistilahkan juga menjadi sign;

(2) Interpretant; bukan penafsir tanda, tetapi lebuh merujuk pada makna dari tanda; dan

(3) Object; sesuatu yang merujuk pada tanda. Sesuatu yang diwakili oleh representamen yang berkaitan dengan acuan. Object dapat berupa representasi mental (ada dalam pikiran) dapat juga berupa sesuatu yang nyata di luar tanda (Vera, 2014:41).

Karena jenis penelitian yang digunakan peneliti adalah penelitian deskriptif, maka data yang dikumpulkan 
adalah berupa kata-kata, gambar, dan bukan angka-angka. Hal itu disebabkan oleh adanya penerapan metode kualitatif.

\section{HASIL PENELITIAN}

Peneliti membagi beberapa bagian pada sampul majalah sebagai berikut:

\section{Objek: 1}

\begin{tabular}{|c|c|c|c|}
\hline SIGN & IKON & INDEKS & SIMBOL \\
\hline & $\begin{array}{l}\text { Seorang } \\
\text { pria, } \\
\text { memakai } \\
\text { kemeja } \\
\text { putih, } \\
\text { berambu } \\
\text { t pendek } \\
\text { dan rapi } \\
\text { berwarn } \\
\text { a hitam }\end{array}$ & 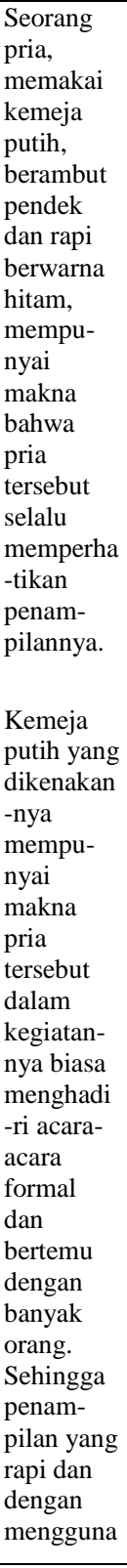 & $\begin{array}{l}\text { Pria yang } \\
\text { digambarkan } \\
\text { pada sampul } \\
\text { majalah } \\
\text { TEMPO } \\
\text { edisi 04 Juni } \\
2018 \\
\text { memakai } \\
\text { kemeja } \\
\text { berwarna } \\
\text { putih. } \\
\text { Warna putih } \\
\text { sendiri } \\
\text { menurut } \\
\text { Rustan, } \\
\text { dalam buku } \\
\text { Mendesain } \\
\text { LOGO (2009 } \\
\text { : 73) } \\
\text { memiliki arti } \\
\text { rendah hati, } \\
\text { suci, netral, } \\
\text { tidak kreatif, } \\
\text { masa muda, } \\
\text { bersih, } \\
\text { netral, } \\
\text { cahaya, } \\
\text { penghor- } \\
\text { matan, } \\
\text { kebenaran, } \\
\text { salju, damai, } \\
\text { innocence } \\
\text { (tidak } \\
\text { bersalah), } \\
\text { simpel, } \\
\text { aman, } \\
\text { dingin, } \\
\text { penyerahan, } \\
\text { takut, tanpa } \\
\text { imajinasi, } \\
\text { udara, } \\
\text { kematian } \\
\text { (tradisi } \\
\text { Timur), } \\
\text { kehidupan, } \\
\text { perkawinan } \\
\text { tradisi } \\
\text { Barat), }\end{array}$ \\
\hline
\end{tabular}

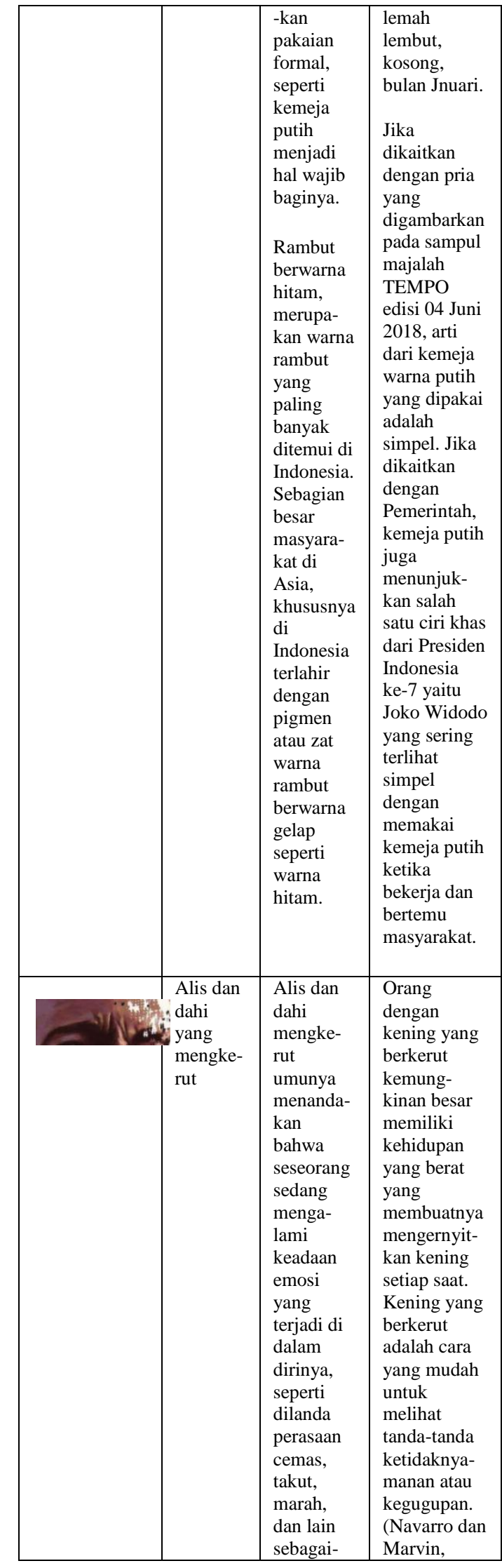




\begin{tabular}{|c|c|c|c|}
\hline & & nya. & $\begin{array}{l}2014: 288) . \\
\text { Jika ada } \\
\text { kerutan } \\
\text { berupa garis- } \\
\text { garis datar } \\
\text { pada dahi } \\
\text { kita, atau } \\
\text { orang yang } \\
\text { kita ajak } \\
\text { bicara, itu } \\
\text { berarti kita } \\
\text { adalah orang } \\
\text { yang } \\
\text { memiliki } \\
\text { antusias } \\
\text { yang amat } \\
\text { tinggi. Kita } \\
\text { adalah tipe } \\
\text { orang yang } \\
\text { penuh energi } \\
\text { dan amat } \\
\text { bersemangat. } \\
\text { Selain itu, } \\
\text { tipe orang } \\
\text { dengan dahi } \\
\text { seperti ini } \\
\text { adalah tipe } \\
\text { yang mudah } \\
\text { sekali marah. } \\
\text { (L Dian, } \\
\text { 2016:55) }\end{array}$ \\
\hline$y$ & \begin{tabular}{|l} 
Sepasan \\
g mata \\
yang \\
berkan- \\
tung \\
tebal \\
tanpa \\
adanya \\
bola \\
mata
\end{tabular} & $\begin{array}{l}\text { Disam- } \\
\text { ping } \\
\text { faktor } \\
\text { bertambah } \\
\text { nya usia, } \\
\text { mata yang } \\
\text { berkan- } \\
\text { tung } \\
\text { menanda- } \\
\text { kan } \\
\text { seseorang } \\
\text { menga- } \\
\text { lami } \\
\text { kelelahan. } \\
\text { Sementara } \\
\text { sepasang } \\
\text { mata } \\
\text { tanpa bola } \\
\text { mata } \\
\text { biasanya } \\
\text { dialami } \\
\text { oleh } \\
\text { seseorang } \\
\text { yang } \\
\text { hampir } \\
\text { tidak } \\
\text { sadarkan } \\
\text { diri dan } \\
\text { bahkan } \\
\text { pingsan. }\end{array}$ & $\begin{array}{l}\text { Banyak } \\
\text { faktor yang } \\
\text { dapat } \\
\text { menyebab- } \\
\text { kan kantung } \\
\text { mata } \\
\text { menjadi } \\
\text { tebal, seperti } \\
\text { salah satunya } \\
\text { adalah faktor } \\
\text { usia. } \\
\text { Semakin } \\
\text { bertambah- } \\
\text { nya usia } \\
\text { seseorang, } \\
\text { mengakibat- } \\
\text { kan kulit } \\
\text { mulai } \\
\text { mengendur, } \\
\text { sehingga } \\
\text { struktur } \\
\text { jaringan otot } \\
\text { yang } \\
\text { menumpu } \\
\text { penutup } \\
\text { mata mulai } \\
\text { lemah. } \\
\text { Selain itu, } \\
\text { faktor lain } \\
\text { yang dapat } \\
\text { menyebab- } \\
\text { kan kantung } \\
\text { mata tebal } \\
\text { adalah } \\
\text { kurang tidur, } \\
\text { reaksi alergi, } \\
\text { serta genetik. }\end{array}$ \\
\hline
\end{tabular}

\begin{tabular}{|c|c|c|c|}
\hline & & & $\begin{array}{l}\text { Sementara } \\
\text { kedua } \\
\text { pasang mata } \\
\text { yang terlihat } \\
\text { tanpa adanya } \\
\text { bola mata } \\
\text { bisa menjadi } \\
\text { suatu } \\
\text { pertanda } \\
\text { seseorang } \\
\text { akan jatuh } \\
\text { pingsan. Hal } \\
\text { ini } \\
\text { disebabkan } \\
\text { karena } \\
\text { malfungsi } \\
\text { pada sistem } \\
\text { saraf otonom } \\
\text { akibat } \\
\text { keadaan } \\
\text { seseorang } \\
\text { yang terlalu } \\
\text { emosional. } \\
\text { Biasanya } \\
\text { dipicu oleh } \\
\text { stress yang } \\
\text { mengakibat- } \\
\text { kan aliran } \\
\text { darah } \\
\text { mengalir } \\
\text { dengan cepat } \\
\text { sehingga } \\
\text { berpotensi } \\
\text { hilangnya } \\
\text { kesadaran } \\
\text { sementara. } \\
\text { Termasuk } \\
\text { kesaran } \\
\text { dalam } \\
\text { mengatur } \\
\text { fokus } \\
\text { penglihatan } \\
\text { seseorang. }\end{array}$ \\
\hline $\cos x$ & $\begin{array}{l}\text { Bibir } \\
\text { tipis } \\
\text { dengan } \\
\text { mulut } \\
\text { yang } \\
\text { terbuka } \\
\text { lebar } \\
\text { sehingga } \\
\text { terlihat } \\
\text { gigi, } \\
\text { gusi dan } \\
\text { air liur. } \\
\text { Terlihat } \\
\text { juga } \\
\text { garis } \\
\text { kerut di } \\
\text { sekitar } \\
\text { mulut }\end{array}$ & $\begin{array}{l}\text { Mulut } \\
\text { yang } \\
\text { terbuka } \\
\text { lebar } \\
\text { disertai } \\
\text { dengan } \\
\text { adanya } \\
\text { garis-garis } \\
\text { air liur } \\
\text { menandak } \\
\text { an } \\
\text { seseorang } \\
\text { sedang } \\
\text { menyam- } \\
\text { paikan } \\
\text { sesuatu } \\
\text { hal } \\
\text { dengan } \\
\text { cara } \\
\text { berteriak } \\
\text { dan } \\
\text { terlihat } \\
\text { dari garis- } \\
\text { garis } \\
\text { disekitar } \\
\text { mulut }\end{array}$ & $\begin{array}{l}\text { Mulut } \\
\text { terbuka lebar } \\
\text { memiliki } \\
\text { makna pria } \\
\text { yang } \\
\text { digambarkan } \\
\text { pada sampul } \\
\text { tersebut } \\
\text { sedang } \\
\text { berteriak. } \\
\text { Sementara } \\
\text { adanya garis- } \\
\text { garis air liur } \\
\text { disebabkan } \\
\text { oleh mulut } \\
\text { yang terus } \\
\text { memproduk- } \\
\text { si kelenjar } \\
\text { air liur. Air } \\
\text { liur } \\
\text { mempunyai } \\
\text { banyak } \\
\text { fungsi, salah } \\
\text { satunya } \\
\text { adalah } \\
\text { mencegah }\end{array}$ \\
\hline
\end{tabular}




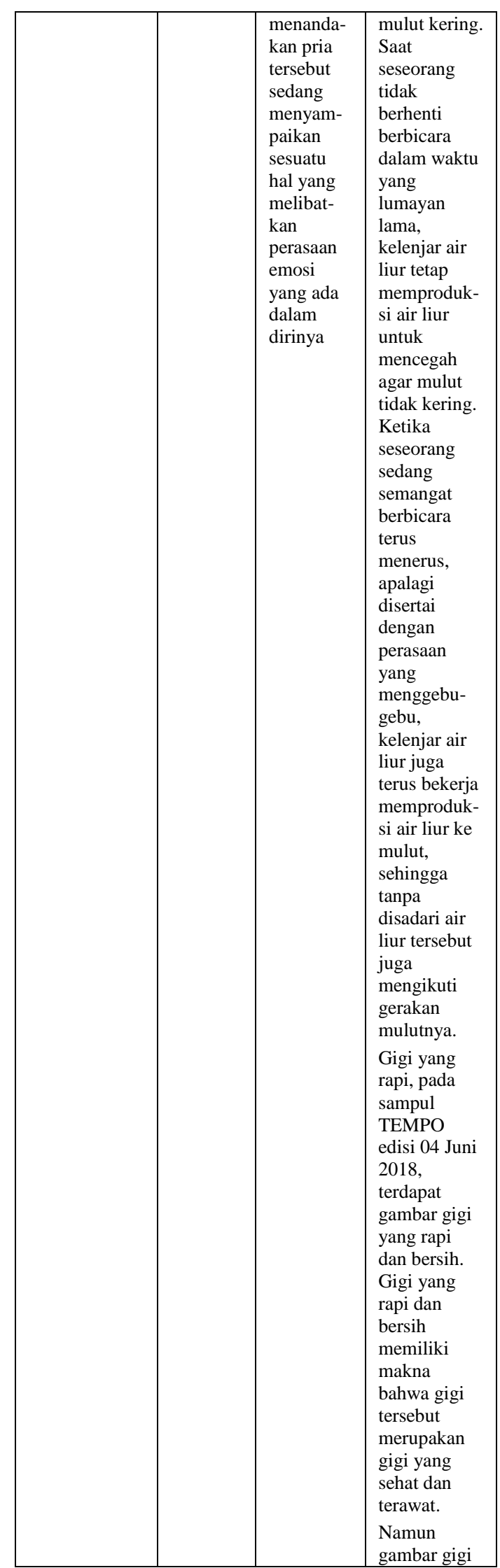

\begin{tabular}{|l|l|l|}
\hline & yang \\
terdapat pada \\
majalah \\
TEMPO \\
edisi 04 Juni \\
2018 hanya \\
gigi seri saja. \\
Tidak ada \\
gigi taring. \\
Yaitu jenis \\
gigi yang \\
runcing dan \\
tajam, \\
dimana \\
fungsi gigi \\
taring adalah \\
untuk \\
mengigit, \\
mengoyak, \\
dan merobek \\
makanan. \\
Memiliki arti \\
bahwa usaha \\
pemerintah \\
dalam \\
memerangi \\
perang tagar \\
dari kubu \\
lain, masih \\
belum bisa \\
'mengigit' \\
atau \\
menghasil- \\
kan dampak \\
keras pada \\
lawan. \\
Terlihat gusi \\
pada mulut \\
bagian \\
bawah. Gusi \\
akan terlihat \\
apabila \\
seseorang \\
membuka \\
lebar \\
mulutnya. \\
Semakin \\
besar rasa \\
emosi yang \\
ingin \\
diluapkan \\
seseorang \\
dengan cara \\
teriak, maka \\
akan \\
semakin \\
besar juga \\
mulutnya \\
terbuka. \\
Terdapat \\
garis-garis \\
wajah dan \\
kerutan \\
disekitar pipi \\
dan leher, \\
semakin \\
bertambah- \\
nya usia \\
pada \\
\hline \\
\end{tabular}




\begin{tabular}{|c|c|c|c|}
\hline & & & $\begin{array}{l}\text { seseorang, } \\
\text { maka garis- } \\
\text { garis wajah } \\
\text { dan kerutan } \\
\text { akan } \\
\text { bertambah } \\
\text { juga. Hal ini } \\
\text { disebabkan } \\
\text { karena } \\
\text { penurunan } \\
\text { kekencangan } \\
\text { otot dan kulit } \\
\text { disekitar } \\
\text { wajah akibat } \\
\text { faktor usia. }\end{array}$ \\
\hline 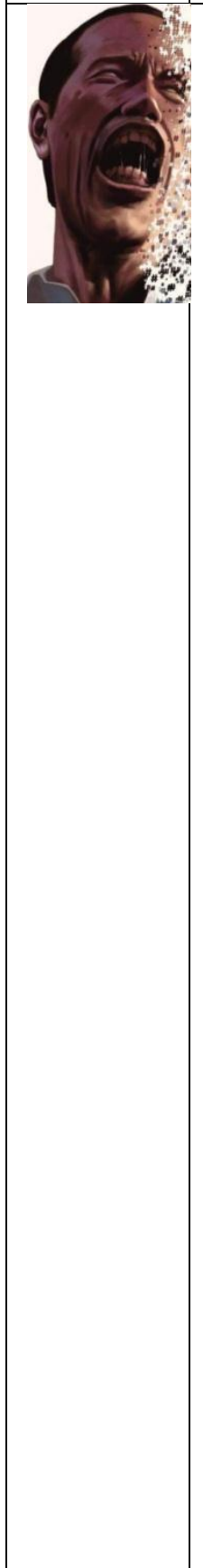 & $\begin{array}{l}\text { Seorang } \\
\text { pria } \\
\text { memiliki } \\
\text { bentuk } \\
\text { wajah } \\
\text { panjang } \\
\text { dengan } \\
\text { posisi } \\
\text { kepala } \\
\text { menga- } \\
\text { rah ke } \\
\text { atas }\end{array}$ & $\begin{array}{l}\text { Terlihat } \\
\text { ekspresi } \\
\text { wajah } \\
\text { yang lebih } \\
\text { jelas pada } \\
\text { saat } \\
\text { seseorang } \\
\text { mengarah } \\
\text {-kan } \\
\text { kepalanya } \\
\text { keatas } \\
\text { daripada } \\
\text { orang } \\
\text { yang } \\
\text { menun- } \\
\text { dukan } \\
\text { wajahnya. } \\
\text { Pada } \\
\text { gambar } \\
\text { tersebut, } \\
\text { terlihat } \\
\text { jelas dari } \\
\text { ekspresi } \\
\text { wajah } \\
\text { yang } \\
\text { ditunjuk- } \\
\text { kan oleh } \\
\text { pria } \\
\text { tersebut } \\
\text { sedang } \\
\text { dalam } \\
\text { keadaan } \\
\text { yang } \\
\text { kurang } \\
\text { baik dan } \\
\text { terlihat } \\
\text { penuh } \\
\text { dengan } \\
\text { tekanan. }\end{array}$ & $\begin{array}{l}\text { Dian L } \\
(2016) \\
\text { menyebutkan } \\
\text { bahwa orang } \\
\text { yang } \\
\text { memiliki } \\
\text { wajah } \\
\text { panjang } \\
\text { memiliki } \\
\text { kesabaran } \\
\text { dan } \\
\text { keteguhan } \\
\text { hati yang } \\
\text { kuat. Ia juga } \\
\text { memiliki } \\
\text { kepribadian } \\
\text { yang } \\
\text { menarik. Ia } \\
\text { juga akan } \\
\text { selalu } \\
\text { berusaha } \\
\text { menyelesai- } \\
\text { kan semua } \\
\text { tugas yang } \\
\text { diberikan } \\
\text { dengan baik } \\
\text { sampai } \\
\text { tuntas. } \\
\text { Dalam buku } \\
\text { Dian L } \\
\text { (2016) } \\
\text { berjudul I } \\
\text { KNOW } \\
\text { YOUR } \\
\text { GESTURE } \\
\text { Trik Jitu } \\
\text { Memahami } \\
\text { Manusia } \\
\text { Lewat Gerak } \\
\text { Gerik Tubuh, } \\
\text { kepala yang } \\
\text { mengarah ke } \\
\text { atas } \\
\text { mempunyai } \\
\text { arti gerakan } \\
\text { ini adalah } \\
\text { gestur yang } \\
\text { sering } \\
\text { dilakukan } \\
\text { oleh orang- } \\
\text { orang yang } \\
\text { merasa } \\
\text { dirinya } \\
\text { berkuasa. }\end{array}$ \\
\hline
\end{tabular}

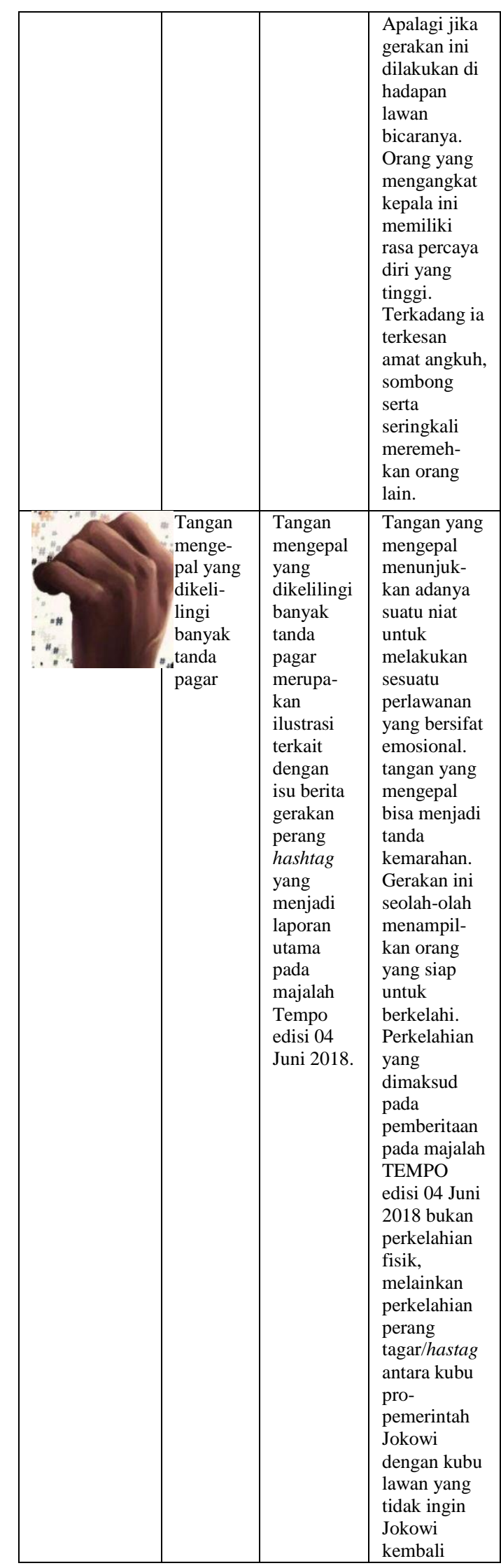




\begin{tabular}{|c|c|c|c|}
\hline & & & $\begin{array}{l}\text { menjabat } \\
\text { sebagai } \\
\text { presiden } \\
\text { pada tahun } \\
2019 \\
\text { mendatang. } \\
\text { Tagar atau } \\
\text { hashtag yang } \\
\text { dimaksud } \\
\text { adalah } \\
\text { \#2019GantiP } \\
\text { residen dan } \\
\text { \#Jokowi2Per } \\
\text { iode yang } \\
\text { marak di } \\
\text { media sosial } \\
\text { twitter dan } \\
\text { instagram. } \\
\text { Tagar dalam } \\
\text { jumlah yang } \\
\text { banyak dan } \\
\text { mempunyai } \\
\text { warna yang } \\
\text { berbeda } \\
\text { melambang- } \\
\text { kan } \\
\text { maraknya } \\
\text { hashtag } \\
\text { \#2019GantiP } \\
\text { residen dan } \\
\text { \#Jokowi2Pe- } \\
\text { riode pada } \\
\text { media sosial. }\end{array}$ \\
\hline 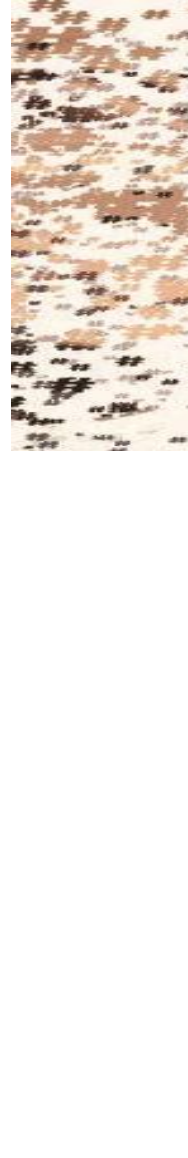 & $\begin{array}{l}\text { Butiran- } \\
\text { butiran } \\
\text { tanda } \\
\text { pagar } \\
\text { (hashtag } \\
\text { ) dengan } \\
\text { warna } \\
\text { dan } \\
\text { ukuran } \\
\text { yang } \\
\text { berbeda } \\
\end{array}$ & $\begin{array}{l}\text { Butiran- } \\
\text { butiran } \\
\text { tanda } \\
\text { pagar } \\
\text { (hashtag) } \\
\text { dengan } \\
\text { warna dan } \\
\text { ukuran } \\
\text { yang } \\
\text { berbeda } \\
\text { melam- } \\
\text { bangkan } \\
\text { maraknya } \\
\text { hashtag } \\
\text { \#2019- } \\
\text { GantiPre- } \\
\text { siden dan } \\
\text { \#Jokowi2 } \\
\text { Periode } \\
\text { pada } \\
\text { media } \\
\text { sosial. }\end{array}$ & $\begin{array}{l}\text { Butiran- } \\
\text { butiran tanda } \\
\text { pagar, alias } \\
\text { Hashtag } \\
\text { alias pound } \\
\text { sign } \\
\text { merupakan } \\
\text { salah satu } \\
\text { fitur yang } \\
\text { dimiliki } \\
\text { Twitter, yang } \\
\text { dirilis pada } \\
\text { Agustus } \\
\text { 2007. Hastag } \\
\text { digunakan } \\
\text { untuk } \\
\text { memudahkan } \\
\text { para } \\
\text { pengguna } \\
\text { Twitter } \\
\text { mengikuti } \\
\text { suatu } \\
\text { perbincangan } \\
\text { dengan tema } \\
\text { tertentu. } \\
\text { Hashtag } \\
\text { yang } \\
\text { dimaksud } \\
\text { pada ilustrasi } \\
\text { sampul } \\
\text { Majalah } \\
\text { TEMPO } \\
\text { edisi 04 Juni } \\
\text { 2018 adalah } \\
\text { \#2019Ganti- } \\
\text { Presiden dan }\end{array}$ \\
\hline
\end{tabular}

\begin{tabular}{|l|l|l|}
\hline & & \#Jokowi2- \\
Periode yang \\
marak di \\
media sosial \\
twitter dan \\
instagram. \\
Tagar/hastag \\
ini \\
merupakan \\
dukungan \\
antara kubu \\
pro- \\
pemerintah \\
Jokowi \\
dengan kubu \\
\\
& lawan yang \\
tidak ingin \\
Jokowi \\
kembali \\
\\
& menjabat \\
& sebagai \\
& presiden \\
& pada tahun \\
& 2019 \\
& mendatang. \\
\hline
\end{tabular}

Tabel 2: Hasil Analisis pada Objek 1

Pada sampul majalah TEMPO edisi 04 Juni 2018, mengenai pemberitaan tentang 'perang \#' digambarkan seorang pria memakai kemeja putih, dengan tekanan wajah emosional dengan mulut yang terbuka, alis yang mengkerut, kepala yang menghadap ke atas dan tangan yang mengepal. Disisi kanan wajah dan tubuh pria tersebut, terdapat butiran-butiran tanda pagar dan terdapat kalimat "PERANG \# ADU KUAT DI MEDIA SOSIAL MENJADI PEMANASAN MENJELANG PEMILU 2019. SIAPA BERADA DI BELAKANG DUA KELOMPOK YANG BERSETERU?'”.

Pemilihan ilustrasi pada sampul edisi 04 Juni 2018 tersebut merupakan makna tersirat dari majalah TEMPO yang mencoba menggambarkan keadaan pemerintah pada masa akhir Jokowi menjabat menjadi Presiden Indonesia ke7 yang tengah menghadapi serangan di media sosial dengan maraknya hastag \#2019GantiPresiden, dari kubu yang kontra terhadap pemerintahan Jokowi 
dan tidak ingin Jokowi kembali menjabat menjadi Presiden pada tahun 2019 mendatang. Dimana serangan hashtag di media sosial ini merupakan bentuk Komunikasi Politik yang dilakukan kedua kubu untuk menarik opini masyarakat di Indonesia.

Lewat sosok pria dengan wajah yang penuh tekanan emosional tersebut, majalah TEMPO menyampaikan makna bahwa meskipun Pemerintah Jokowi merasakan ketidaknyamanan dan kecemasan melalui hashtag \#2019GantiPresiden yang dilayangkan kepada kubunya, pemerintah Jokowi berupaya menepis segala isu-isu negatif. Pemerintahan Jokowi, dibantu relawannya gigih memposting hasil kinerja selama masa pemerintahan Jokowi lewat hashtag \#Jokowi2Periode lewat media sosial instagram dan twitter. Pemerintahan Jokowi memiliki determinasi yang kuat bahwa citra positif terhadap pemerintahan Jokowi masih melekat pada opini masyarakat.

Selain terdapat gambar ilustrasi seorang pria, terdapat juga kalimat "PERANG \# ADU KUAT DI MEDIA SOSIAL MENJADI PEMANASAN MENJELANG PEMILU 2019. SIAPA BERADA DI BELAKANG DUA KELOMPOK YANG BERSETERU?" yang merupakan tema pemberitaan utama pada majalah TEMPO edisi 04 Juni 2018. Penulisan kalimat tersebut menggunakan huruf besar (kapital) jenis Sans Serif berwarna hitam yang memiliki arti efisien dan misteri. Efisien yaitu pemilihan font yang mudah dibaca ini adalah tujuan dari majalah TEMPO yang ingin langsung memberitahukan kepada pembacanya bahwa edisi kali ini membahas mengenai perang \#.

Sementara tangan yang mengepal bisa menjadi tanda kemarahan. Gerakan ini seolah-olah menampilkan orang yang siap untuk berkelahi. Perkelahian yang dimaksud pada pemberitaan pada majalah TEMPO edisi 04 Juni 2018 bukan perkelahian fisik, melainkan perkelahian perang tagar/hastag antara kubu pro-pemerintah Jokowi dengan kubu lawan yang tidak ingin Jokowi kembali menjabat sebagai presiden pada tahun 2019 mendatang. Tagar atau hashtag yang dimaksud adalah \#2019GantiPresiden dan \#Jokowi2Periode yang marak di media sosial twitter dan instagram.

Namun majalah TEMPO tidak menggambarkan tangan yang mengepal secara mantap, mengingat pembahasan sebelumnya, kubu pro pemerintah Jokowi merasa gugup, takut, dan cemas dalam menghadapi serangan \#2019GantiPresiden dari kubu lawan.

\section{Objek 2:}

\begin{tabular}{|c|c|c|c|}
\hline SIGN & IKON & INDEKS & SIMBOL \\
\hline TEM & $\begin{array}{l}\text { Nama } \\
\text { majalah } \\
\text { TEMPO } \\
\text { dan } \\
\text { tagline } \\
\text { "ENAK } \\
\text { DIBACA } \\
\text { DAN } \\
\text { PERLU" } \\
\text { Huruf } \\
\text { kapital } \\
\text { berwarna } \\
\text { coklat. } \\
\text { Tanda } \\
\text { Pagar } \\
\text { Back- } \\
\text { ground } \\
\text { berwarna } \\
\text { putih. }\end{array}$ & $\begin{array}{l}\text { Kalimat } \\
\text { bertuliskan } \\
\text { "TEMPO” } \\
\text { dan ““'ENAK } \\
\text { DIBACA } \\
\text { DAN } \\
\text { PERLU” } \\
\text { menunjuk- } \\
\text { kan ciri khas } \\
\text { dari majalah } \\
\text { TEMPO. } \\
\text { Pada latar } \\
\text { belakang di } \\
\text { BAB 1, } \\
\text { peneliti } \\
\text { menyertakan } \\
\text { gambar } \\
\text { sampul } \\
\text { majalah } \\
\text { TEMPO } \\
\text { edisi Januari } \\
\text { 2018 hingga } \\
\text { Juni } 2018 \text {. } \\
\text { dapat dilihat } \\
\text { jenis font } \\
\text { dan } \\
\text { kalimatnya } \\
\text { sama. Hanya } \\
\text { warna yang } \\
\text { berubah. }\end{array}$ & $\begin{array}{l}\text { Penulisan kata } \\
\text { "TEMPO" } \\
\text { dan tagline } \\
\text { "ENAK } \\
\text { DIBACA } \\
\text { DAN } \\
\text { PERLU" } \\
\text { ditulis } \\
\text { menggunakan } \\
\text { huruf kapital } \\
\text { menggunakan } \\
\text { font ROMAN } \\
\text { jenis Times } \\
\text { New Roman, } \\
\text { namun pada } \\
\text { huruf "M" } \\
\text { jenis font yang } \\
\text { digunakan } \\
\text { adalah font } \\
\text { Century } \\
\text { Gothic, } \\
\text { dimana Font } \\
\text { ROMAN } \\
\text { menurut } \\
\text { James Craig, } \\
\text { yaitu huruf ini } \\
\text { memiliki } \\
\text { sirip/kaki/serif } \\
\text { yang } \\
\text { berbentuk } \\
\text { lancip pada } \\
\text { ujungnya. }\end{array}$ \\
\hline
\end{tabular}




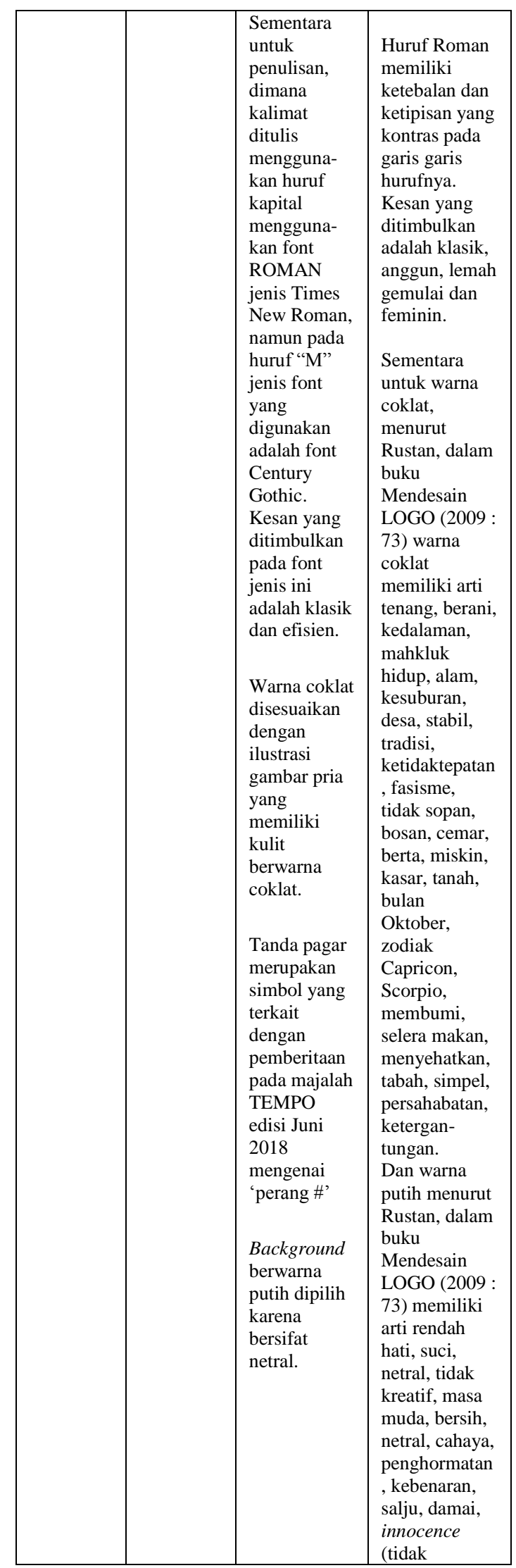

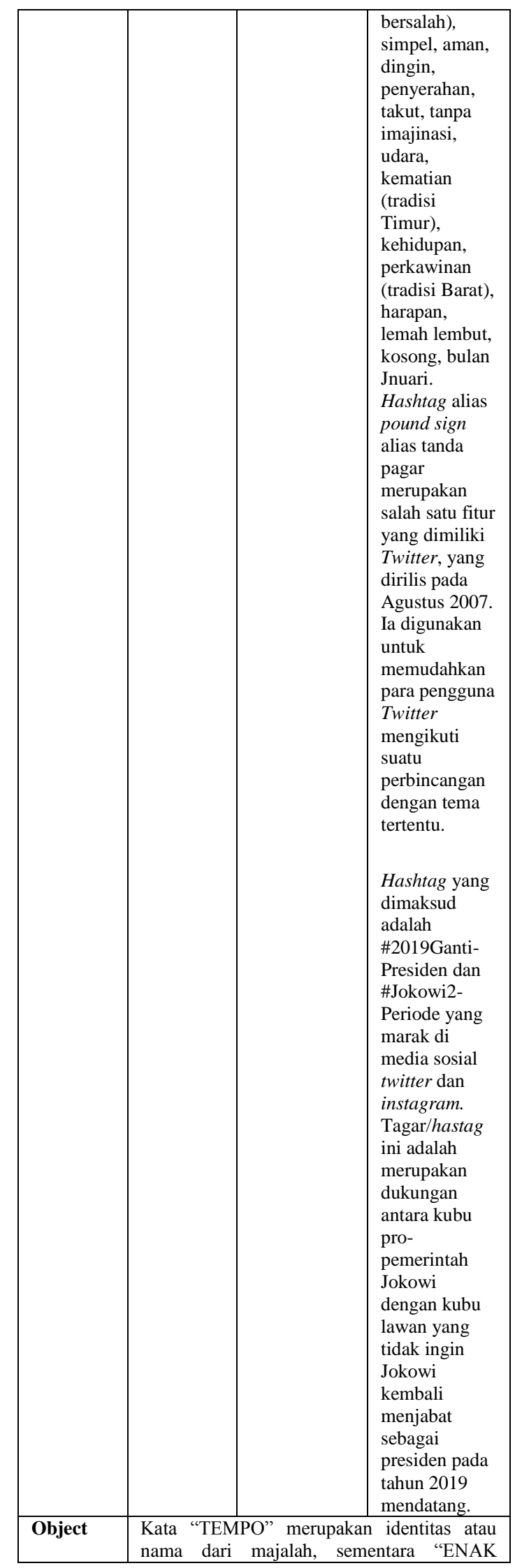




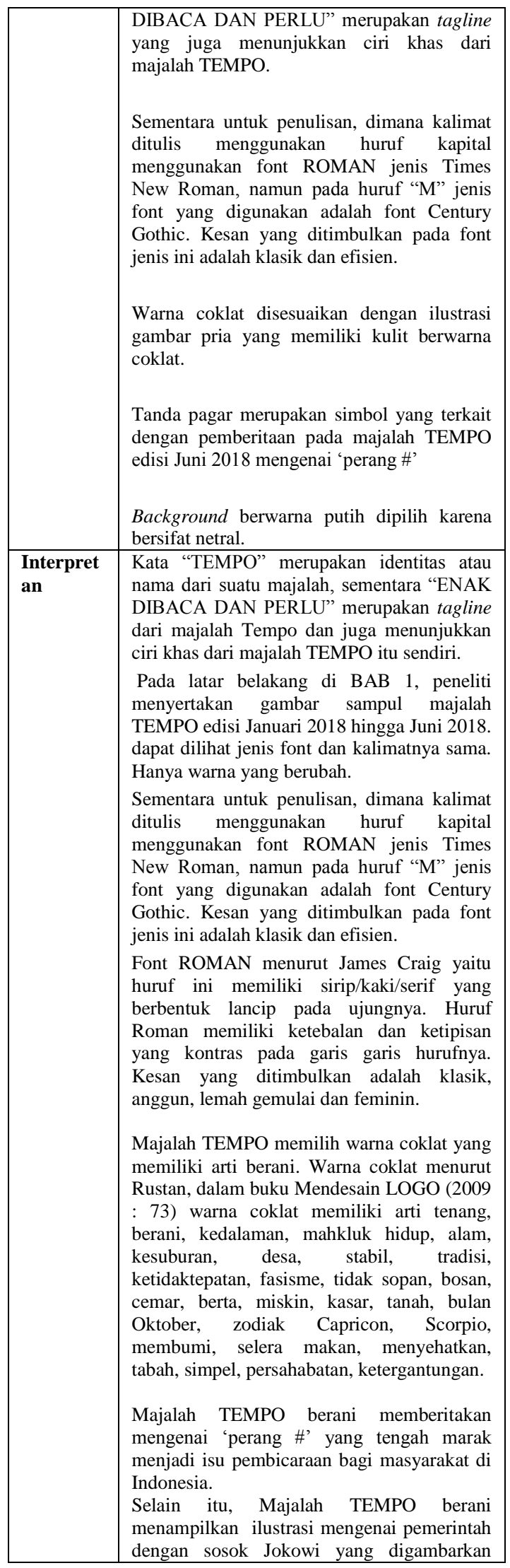

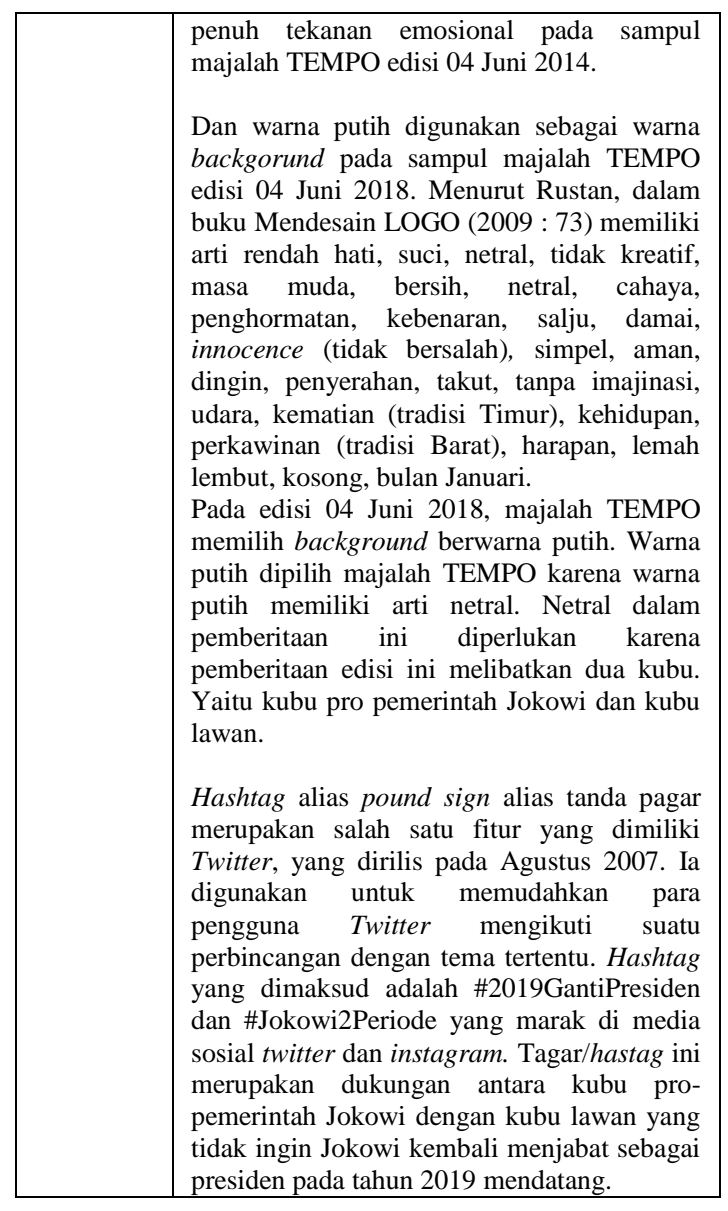

Tabel 3: Hasil Analisis pada Objek 2

Nama majalah TEMPO dan tagline "ENAK DIBACA DAN PERLU" menunjukkan ciri khas dari majalah TEMPO. Kata "TEMPO" dan "ENAK DIBACA DAN PERLU" menggunakan huruf kapital font ROMAN jenis Times New Roman, namun pada huruf "M" jenis font yang digunakan adalah font Century Gothic. Kesan yang ditimbulkan pada font ini adalah klasik, anggun, lemah gemulai dan feminin.

Pemilihan warna coklat pada kata "TEMPO" dan "ENAK DIBACA DAN PERLU" yang memiliki arti berani. Warna coklat menurut Rustan (2009: 73): "warna coklat memiliki arti tenang, berani..." Arti berani disini adalah Majalah TEMPO berani memberitakan mengenai 'perang \#' yang tengah marak 


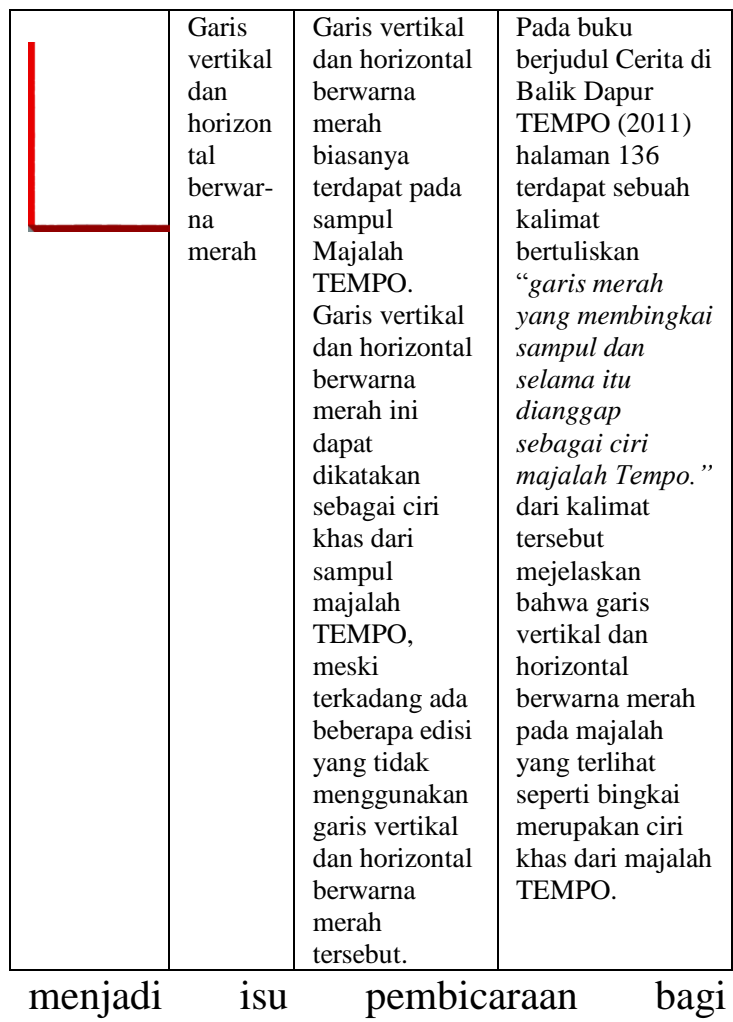
masyarakat di Indonesia. Selain itu, Majalah TEMPO berani menampilkan ilustrasi mengenai pemerintah dengan sosok Jokowi yang digambarkan penuh tekanan emosional pada sampul majalah TEMPO edisi 04 Juni 2014.

\section{Sedangkan warna putih} digunakan sebagai warna backgorund pada sampul majalah TEMPO edisi 04 Juni 2018. Masih menurut Rustan, dikatakan bahwa "warna putih memiliki arti rendah hati, suci, netral, ...." Netral dalam pemberitaan ini diperlukan karena pemberitaan edisi ini melibatkan dua kubu. Yaitu kubu pro pemerintah Jokowi dan kubu lawan.

Sementara untuk tanda pagar pada kata "TEMPO" dan "ENAK DIBACA DAN PERLU" merupakan tagar/hastag yang ditujukan untuk memberikan dukungan antara kubu propemerintah Jokowi dengan kubu lawan yang tidak ingin Jokowi kembali menjabat sebagai presiden pada tahun
2019 mendatang. Tanda pagar "\#” atau hashtag yang dimaksud adalah \#2019GantiPresiden dan \#Jokowi2Periode yang marak di media sosial twitter dan instagram.

\section{Objek: 3}

\begin{tabular}{|l|l|}
\hline Objek & $\begin{array}{l}\text { Terdapat garis horizontal dan vertikal } \\
\text { berwarna merah seperti sebuah bingkai pada } \\
\text { sampul majalah TEMPO edisi 04 Juni } 2018 .\end{array}$ \\
\hline Interpretan & $\begin{array}{l}\text { Adanya garis horizontal dan vertikal berwarna } \\
\text { merah pada sampul majalah TEMPO edisi 04 } \\
\text { Juni 2018 merupakan ciri khas dari majalah } \\
\text { TEMPO. }\end{array}$ \\
\hline
\end{tabular}

Tabel 4: Hasil Analisis pada Objek 3

Setiap majalah pasti mempunyai suatu ciri khas atau keunikan tersendiri yang bertujuan untuk membedakan antara satu majalah dengan majalah yang lainnya. Seperti yang dilakukan oleh majalah TEMPO dalam menunjukkan ciri khas dan keunikan majalahnya, yaitu berupa garis horizontal dan vertikal yang berwarna merah dan juga ada jika diperhatikan lebih teliti, terdapat segitiga siku-siku kecil berwarna abu-abu pada sudut antara garis horizontal dan vertikal yang ada pada sampul majalah TEMPO. Adanya garis horizontal dan vertikal berwarna merah yang menyerupai seperti sebuah bingkai tidak hanya terdapat pada majalah TEMPO edisi 04 Juni 2018 saja, namun garis horizontal dan vertikal berwarna merah ini juga dapat ditemukan pada Majalah TEMPO edisi sebelumnya.

\section{Diskusi}

Pada sampul majalah TEMPO edisi 04 Juni 2018, mengenai pemberitaan tentang 'perang \#' digambarkan seorang pria memakai kemeja putih, dengan tekanan wajah emosional dengan mulut yang terbuka, alis yang mengkerut, kepala yang menghadap ke atas dan tangan yang mengepal. Disisi kanan wajah dan tubuh pria tersebut, terdapat 
butiran-butiran tanda pagar dan terdapat kalimat "PERANG \# ADU KUAT DI MEDIA SOSIAL MENJADI PEMANASAN MENJELANG PEMILU 2019. SIAPA BERADA DI BELAKANG DUA KELOMPOK YANG BERSETERU?".

Pemilihan ilustrasi pada sampul edisi 04 Juni 2018 tersebut merupakan makna tersirat dari majalah TEMPO yang mencoba menggambarkan keadaan pemerintah pada masa akhir Jokowi menjabat menjadi Presiden Indonesia ke-7 yang tengah menghadapi serangan di media sosial dengan maraknya hastag \#2019GantiPresiden, dari kubu yang kontra terhadap pemerintahan Jokowi dan tidak ingin Jokowi kembali menjabat menjadi Presiden pada tahun 2019 mendatang. Dimana serangan hashtag di media sosial ini merupakan bentuk Komunikasi Politik yang dilakukan kedua kubu untuk menarik opini masyarakat di Indonesia.

Lewat sosok pria dengan wajah yang penuh tekanan emosional tersebut, majalah TEMPO menyampaikan makna bahwa meskipun Pemerintah Jokowi merasakan ketidaknyamanan dan kecemasan melalui hashtag \#2019GantiPresiden yang dilayangkan kepada kubunya, pemerintah Jokowi berupaya menepis segala isu-isu negatif. Pemerintahan Jokowi, dibantu relawannya gigih memposting hasil kinerja selama masa pemerintahan Jokowi lewat hashtag \#Jokowi2Periode lewat media sosial instagram dan twitter. Pemerintahan Jokowi memiliki determinasi yang kuat bahwa citra positif terhadap pemerintahan Jokowi masih melekat pada opini masyarakat.

Selain terdapat gambar ilustrasi seorang pria, terdapat juga kalimat "PERANG \# ADU KUAT DI MEDIA SOSIAL MENJADI PEMANASAN MENJELANG PEMILU 2019. SIAPA BERADA DI BELAKANG DUA KELOMPOK YANG BERSETERU?" yang merupakan tema pemberitaan utama pada majalah TEMPO edisi 04 Juni 2018. Penulisan kalimat tersebut menggunakan huruf besar (kapital) jenis Sans Serif berwarna hitam yang memiliki arti efisien dan misteri. Efisien yaitu pemilihan font yang mudah dibaca ini adalah tujuan dari majalah TEMPO yang ingin langsung memberitahukan kepada pembacanya bahwa edisi kali ini membahas mengenai perang \#.

Sementara tangan yang mengepal bisa menjadi tanda kemarahan. Gerakan ini seolah-olah menampilkan orang yang siap untuk berkelahi. Perkelahian yang dimaksud pada pemberitaan pada majalah TEMPO edisi 04 Juni 2018 bukan perkelahian fisik, melainkan perkelahian perang tagar/hastag antara kubu pro-pemerintah Jokowi dengan kubu lawan yang tidak ingin Jokowi kembali menjabat sebagai presiden pada tahun 2019 mendatang. Tagar atau hashtag yang dimaksud adalah \#2019GantiPresiden dan \#Jokowi2Periode yang marak di media sosial twitter dan instagram.

Namun majalah TEMPO tidak menggambarkan tangan yang mengepal secara mantap, mengingat pembahasan sebelumnya, kubu pro pemerintah Jokowi merasa gugup, takut, dan cemas dalam menghadapi serangan \#2019GantiPresiden dari kubu lawan.

Pada kata "TEMPO" dan "ENAK DIBACA DAN PERLU" majalah TEMPO menggunakan jenis font ROMAN berwarna coklat. Dimana pemilihan font dan warna tersebut memiliki kesan klasik dan berani. Arti berani disini adalah Majalah TEMPO berani memberitakan mengenai 'perang \#' yang tengah marak menjadi isu pembicaraan bagi masyarakat di Indonesia dan berani menampilkan ilustrasi mengenai pemerintah dengan sosok Jokowi yang digambarkan penuh tekanan emosional pada sampul majalah TEMPO edisi 04 Juni 2014.

\section{PENUTUP}

\section{Simpulan}

Dari hasil analisis mengunakan model Semiotika Pierce berdasarkan teori segitiga makna, yaitu: sign, object, dan interpretant, peneliti berhasil 
memperoleh makna pada sampul Majalah TEMPO edisi 04 Juni 2018, dimana majalah TEMPO melalui grafis dan teks pada sampul majalah TEMPO edisi 04 Juni 2018 menggambarkan keadaan pemerintah pada masa akhir Jokowi menjabat sebagai Presiden Indonesia ke7 tengah merasakan ketidaknyamanan dan kecemasan akibat maraknya serangan hastag \#2019GantiPresiden di media sosial twitter dan instagram yang berasal dari pihak-pihak yang kontra terhadap pemerintahan Jokowi dan tidak ingin Jokowi kembali menjabat menjadi presiden di 2019 mendatang.

Lewat sosok pria dengan wajah yang penuh tekanan emosional tersebut dan banyaknya tanda pagar atau hashtag dari sebelah kanan dirinya, majalah TEMPO menyampaikan makna bahwa meskipun Pemerintah Jokowi merasakan ketidaknyamanan dan kecemasan melalui hashtag \#2019GantiPresiden yang dilayangkan kepada kubunya, pemerintah Jokowi terus berupaya menepis segala isu-isu negatif. Pemerintahan Jokowi, dibantu relawannya gigih memposting hasil kinerja selama masa pemerintahan Jokowi lewat hashtag \#Jokowi2Periode melalui media sosial instagram dan twitter.

Terdapat unsur komunikasi politik pada "perang \#" antar dua kubu yang berseteru yang sedang marak di media sosial. Komunikasi politik tersebut terjadi dengan adanya pengoperan lambang-lambang atau simbol-simbol komunikasi yang berisi pesan-pesan politik dari seseorang atau kelompok kepada orang lain yaitu berupa sebuah postingan atau cuitan pada media sosial Facebook, Twitter, Instagram, dan sebagainya yang menyertakan tanda pagar '\#' atau yang biasa disebut hastag.

Oleh karena itu, Majalah TEMPO menyertakan teks berupa tanda pagar atau hashtag dengan ukuran yang besar pada sampul majalah TEMPO edisi 04 Juni 2018 dengan isu pemberitaan "Perang \#" karena hashtag di media sosial bukan hanya sebagai sebuah fitur yang ada pada media sosial. Lebih dari itu, hashtag mempunyai kekuatan untuk mengubah opini masyarakat luas. Terlebih lagi di era informasi dan komunikasi saat ini, media sosial menjadi sarana yang efektif dan efisien untuk kegiatan kampanye secara online.

Adanya perang hashtag dari kedua kubu dengan hashtag andalannya masing-masing, \#2019GantiPresiden dan \#Jokowi2Periode merupakan salah satu bentuk komunikasi politik dari masingmasing kubu kepada target politiknya, yaitu masyarakat Indonesia yang sudah mempunyai hak dan kewajiban untuk memilih dan memberikan suara mereka pada pemilu April 2019.

Tujuannya adalah untuk mendapatkakan simpati, opini, dan suara rakyat sebanyak-banyaknya. Jika tidak karena demikian, pemerintahan pada masa Jokowi tentunya tidak perlu merasa cemas, gugup hingga membalas serangan hashtag dari kubu lawan, seperti yang diilustrasikan pada Majalah TEMPO edisi 04 Juni 2018.

\section{Saran}

Saran untuk majalah TEMPO, jika mengangkat pemberitaan mengenai isu yang melibatkan lebih dari satu pihak, dalam hal ini yaitu dua pihak, sebaiknya gambar yang mengilustrasikan kedua belah pihak juga disertakan dalam sampul majalah.

Pada edisi 04 Juni 2018, terlihat hanya terdapat gambar ilustrasi satu kubu saja, sementara kubu lawan tidak dimuat pada sampul majalah TEMPO edisi 04 Juni 2018, padahal edisi ini membahas 
mengenai dua kubu yang berseteru. Yaitu kubu pro pemerintahan Jokowi dan kubu lawan dan dipertegas dengan kalimat "Perang \# ADU KUAT DI MEDIA SOSIAL MENJADI PEMANASAN MENJELANG PEMILU 2019. SIAPA BERADA DI BELAKANG DUA KELOMPOK YANG BERSETERU?"

Ada baiknya hal ini perlu dipertimbangkan agar tidak terjadi salah persepsi antara pihak majalah TEMPO dengan pembaca dalam mengartikan makna dari sampul edisi 04 Juni 2018 dan sampul majalah TEMPO edisi kedepannya. Karena sampul majalah juga menjadi salah satu dari banyaknya faktor yang menjadikan khalayak atau konsumen memutuskan untuk membeli sebuah majalah.

\section{DAFTAR PUSTAKA}

Althoff, Phillip \& Rush, Michael. 2008. Pengantar Sosiologi Politik. Jakarta: PT Raja Grafindo Persada.

Alan \& Pease, Barbara. 2018. Kitab Bahasa Tubuh: Memahami Orang Lain Melalui Bahasa Tubuhnya. Jakarta: Gramedia Pustaka Utama.

Atmoko, Bambang Dwi. 2012. Instagram Handbook. Jakarta: Media Kita.

Biagi, Shirley. 2010. Media/Impact: Pengantar Media Massa, Edisi 9. Penerjemah Mochammad Irfan dan Wulung Wira M. Jakarta: Salemba Humanika.

Cangara, Hafied. 2010. Pengantar Ilmu Komunikasi. Jakarta: Rajawali Pers.

Danton, Sihombing. 2015. Tipografi Dalam Desain Grafis. Jakarta: Gramedia Pustaka Utama.

Departemen Pendidikan Nasional. 2008. Kamus Besar Bahasa Indonesia. Jakarta; Balai Pustaka.
Effendy, Onong Uchjana. 2008. Dinamika Komunikasi. Bandung: PT. Remaja Rosdakarya.

Junaedhie Kurniawan. 2010. Ensiklopedi Pers Indonesia. Jakarta: Gramedia Pustaka Utama.

Kusrianto, Adi. 2010. Pengantar Tipografi. Jakarta: PT. Elex Media Komputindo.

L, Dian. 2016. I Know Your Gesture. Trik Jitu Memahami Manusia Lewat Gerak Gerik Tubuh. Yogyakarta: Pustaka Baru Press.

Liliweri, Alo. 2011. Komunikasi Serba Ada Serba Makna. Jakarta: Prenada Media Group.

Littlejohn, Stephen W \& Karen A. Foss. 2014. Teori Komunikasi. Jakarta: Salemba Humanika.

Manzilati, Asfi. 2017. Metodologi Penelitian Kualitatif: Paradigma, Metode, dan Aplikasi. Malang: Universitas Brawijaya Press.

Moleong, Lexy J. 2010. Metode Penelitian Kualitatif. Bandung: PT Remaja Rosdakarya.

Nasrullah, Rulli. 2015. Media Sosial Perspektif Komunikasi, Budaya, dan Sosioteknologi. Bandung: PT Remaja Rosdakarya.

Navarro Joe dan Marvin Karlins. 2014. Cara Cepat Membaca Bahasa Tubuh. Jakarta: Change Creative.

Nurudin. 2011. Pengantar Komunikasi Massa. Jakarta: PT. Rajagrafindo Persada.

Putra, Dedi Kurnia Syah. 2012. Media dan Politik: Menemukan Relasi Antara Dimensi SimbiosisMutualisme Media dan Politik. Tangerang: Graha Ilmu.

Putra, Dinata Eka. 2008. Membaca Pikiran Orang Lewat Bahasa Tubuh. Bandung: Kaifa. 
Rolnicki, E, Tom , Tate, C. Dow, Taylor, A. Sherri. 2008. Pengantar Dasar Jurnalisme. Jakarta: Kencana.

Rustan, Surianto. 2008. Layout Dasar \& Penerapannya. Jakarta: PT Gramedia.

Rustan, Surianto. 2009. Mendesain Logo. Jakarta: PT Gramedia.

Rustan, Surianto. 2011. Huruf Font Tipografi. Jakarta: PT Gramedia.

Santoso, Edi dan Mite Setianasah. 2010. Teori Komunikasi. Yogyakarta: Graha Ilmu.

Sobur, Alex. 2009. Semiotika Komunikasi. Bandung: PT Remaja Rosdakarya.

Suhandang, Kustadi. 2016. Pengantar Jurnalistik Seputar Organisasi, Produk, \& Kode Etik. Bandung: Nuansa

Supriyatno, Makmur. 2016. Tentang Perang Bagian 1: Terjemahan Buku 1,2, \& 3 On War Carl Von Clausewitz. Jakarta: Makmur Cahaya Ilmu.

Sudaryat, Yayat. 2009. Makna dalam Wacana. Bandung: CV Yrama Widya.

Vera, Nawiroh. 2014. Semiotika dalam Riset Komunikasi. Bogor: Ghalia Indonesia.

Venus, Antar. 2009. Manajemen Kampanye. Bandung: Simbiosa Rekatama Media.

Waluyanto, Heri, Dwi. 2000. Karikatur Sebagai Karya Komunikasi Visual dalam Penyampaian Kritik Sosial. Surabaya: Nirm Journal Vol. 2 UKP.

Wibowo, Indiwan Seto Wahyu. 2011. Semiotika Komunikasi-Aplikasi Praktis bagi Penelitian dan Skripsi Komunikasi. Jakarta: Mitra Wacana Media.

https://www.researchgate.net/publication /318790547_ANALISIS_SEMIOTIK ATAS_SAMPUL_MAJALAH_TEMP
O_JAKARTA_RIZAL_RAMLI_PETA

RUNG_ATAU_PERAUNG diakses pada 20 Oktober 2018

Rusmulyadi \& Hafiar, Hanny. 2018 Dekonstruksi Citra Politik Jokowi dalam Media Sosial. https://www.researchgate.net/publica tion/326992724_Dekonstruksi_Citra Politik_Jokowi_Dalam_Media_Sosial diakses pada 20 Oktober 2018

Hutagalung, May Smirnof. 2016. Analisis Semiotika Foto Jurnalistik Kampanye Pilpres 2014 Dalam Kompas Cyber Media. Other thesis, UPN "Veteran" Yogyakarta

Https://eprints.upnyk.ac.id/553/ diakses pada 20 Oktober 2018

https://majalah.tempo.co/edisi/2382/201 8-06-03 diakses pada 24 Agustus 2018

https://infopemilu.kpu.go.id/pilpres2019 diakses pada 30 Agustus 2018

https://tirto.id/evolusi-tagar-dari-simboldigital-jadi-perang-slogan-dunianyata-cJFy diakses pada 31 Agustus 2018

https://www.researchgate.net/publi cation/326992724_Dekonstruks i_Citra_Politik_Jokowi_Dalam Media_Sosial diakses pada 20 Oktober 2018

http://eprints.upnyk.ac.id/553/ diakses pada 20 Oktober 2018 https://korporat.tempo.co/tentang/sejara $\underline{h}$ diakses pada 19 November 2018

Majalah TEMPO edisi 04 Juni 2018 "PERANG \# ADU KUAT DI MEDIA SOSIAL MENJADI PEMANASAN MENJELANG PEMILU 2019. SIAPA BERADA DI BELAKANG DUA KELOMPOK YANG BERSETERU?" 